\title{
PENINGKATAN PENGETAHUAN BAGI KELOMPOK PEMUDA WONOKROMO II DI BIDANG OTOMOTIF UNTUK MENINGKATKAN KETAHANAN EKONOMI KELUARGA
}

\author{
Abdul Haris Subarjo ${ }^{1}$, Wita Setianingsih ${ }^{2}$ \\ ${ }^{1}$ Teknik Mesin, Sekolah Tinggi Teknologi Adisutjipto \\ ${ }^{2}$ Fakultas MIPA, Universitas Negeri Yogyakarta \\ email: ab.haris.79@gmail.com¹,wita@uny.ac.id²
}

\begin{abstract}
ABSTRAK
Ketahanan Nasional merupakan sebuah kondisi dinamis suatu Bangsa, yang merupakan kemampuan Bangsa menghadapi ancaman, gangguan, tantangan, hambatan dari dalam Negeri maupun Luar Negeri. Ketahanan Nasional diawali ketahanan ekonomi keluarga, salah satu cara meningkatkan ketahanan ekonomi keluarga dengan meningkatkan kesejahteraan. Lokasi mitra terletak di Desa Wonokromo yang berada di pinggiran kota Yogyakarta. Di Desa Wonokromo sebagian besar penduduk memiliki kendaraan bermotor, hal ini merupakan peluang untuk berwirausaha. Metode kegiatan pengabdian masyarakat dengan presentasi dan pembagian modul, diharapkan setelah adanya presentasi pengetahuan peserta menjadi meningkat. Indikator peningkatan ditentukan dengan kemampuan menjawab pertanyaan dan antusiasme peserta dalam mengikuti kegiatan. Setelah dilakukan presentasi terdapat peningkatan pengetahuan, pada awal kegiatan pengabdian masyarakat hanya terdapat $40 \%$ peserta yang bisa menjawab pertanyaan, namun pada akhir kegiatan pengabdian masyarakat $100 \%$ peserta bisa menjawab pertanyaan dari presenter dari peserta. Antusiasme peserta cukup baik ditandai dengan tidak ada peserta yang keluar ruangan, peserta mengikuti kegiatan dari awal sampai akhir.
\end{abstract}

Kata Kunci : Pengetahuan, Pemuda Wonokromo, Ketahanan Ekonomi, Kewirausahaan, Otomotif.

\section{ABSTRACT}

National Resilience is a dynamic condition of a Nation, which is the Nation's ability to face threats, disturbances, challenges, obstacles from within the country and abroad. National Resilience begins with family economic resilience, one way to improve family economic resilience by increasing welfare. Partner location is located in the village of Wonokromo which is on the outskirts of the city of Yogyakarta. In Wonokromo Village, the majority of the population owns motorized vehicles, this is an opportunity for entrepreneurship. The method of community service activities with the presentation and distribution of modules is expected to increase after the presentation of participants' knowledge. Indicators of improvement are determined by the ability to answer questions and the enthusiasm of participants in participating in activities. After the presentation there was an increase in knowledge, at the beginning of the community service activity there were only $40 \%$ of participants who could answer questions, but at the end of the community service activity $100 \%$ of the participants could answer questions from the presenter from the participant. The enthusiasm of the participants was quite well marked by no participants leaving the room, participants followed the activity from beginning to end.

Keywords: Knowledge, Wonokromo Youth, Economic Resilience, Entrepreneurship, Automotive. 


\section{PENDAHULUAN}

Kelompok Pemuda Wonokromo II terletak di desa Wonokromo, kecamatan Pleret, kabupaten Bantul. Di daerah Wonokromo terdapat jalan utama untuk menjangkau daerah wisata mangiran. Di sekitar daerah Wonokromo terdapat daerah yang menjadi pasar onderdil otomotif, baik onderdil baru maupun bekas. Saat ini Kelompok Pemuda Wonokromo cukup aktif mengadakan kegiatan untuk meningkatkan kemampuan sumber daya manusia. Kelompok Pemuda Wonokromo memiliki anggota dengan berbagai latar belakang dari sisi ekonomi dan pendidikannya, namun sebagian besar masih bersekolah. Dengan latar belakang tersebut sehingga membutuhkan bimbingan dalam beraktivitas, baik aktivitas fisik maupun non fisik. Prioritas permasalahan yang akan diselesaikan dengan pengetahuan otomotif dapat mendukung dalam hal penyaluran hoby dan meningkatkan penghasilan. Hal ini diharapkan juga dapat terjadi pada kelompok Pemuda Wonokromo II.

Ketahanan keluarga sangat menentukan terhadap tercapainya ketahanan daerah atau wilayah, dengan ketahanan daerah pada akhirnya akan menentukan tercapainya ketahanan nasional. Salah satu bagian dari ketahanan keluarga adalah ketahanan ekonomi keluarga. Untuk meningkatkan Ketahanan Ekonomi Keluarga dapat dengan cara meningkatkan keterampilan otomotif (Subarjo, 2019). Ketahanan ekonomi nasional merupakan ketahanan yang dapat tercermin dalam kondisi kehidupan perekonomian bangsa dan negara, yang mengandung kemampuan dalam memelihara stabilitas ekonomi yang baik, sehat dan dinamis serta kemampuan menciptakan kemandirian ekonomi nasional dengan tingkat daya saing tinggi dan bisa mewujudkan kemakmuran rakyat yang adil dan merata (Marlinah L, 2017). Dengan meningkatnya keterampilan otomotif anggota kelompok pemuda maka diharapkan dapat digunakan untuk menciptakan peluang wirausaha. Apabila telah tercipta lapangan kerja maka akan meningkatkan penghasilan anggota kelompok pemuda. Peningkatan penghasilan anggota kelompok pemuda dapat meningkatkan ketahanan ekonomi keluarga anggota kelompok pemuda.

Penelitian mengenai pelatihan berpengaruh terhadap ketahanan ekonomi masyarakat diteliti oleh Nasution, A.P. (2019). Dengan kesimpulan pendidikan tidak berpengaruh terhadap ketahanan ekonomi masyarakat. Pelatihan berpengaruh terhadap ketahanan ekonomi masyarakat. Modal tidak serta merta berpengaruh terhadap ketahanan ekonomi masyarakat. Terakhir, teknologi menjadi variabel paling dominan berpengaruh terhadap ketahanan ekonomi masyarakat. Penelitian lain dilakukan oleh Nursaid, A. (2016) tujuan penelitian untuk mengetahui aktivitas dan produktivitas kelompok batik tulis 
Sekar Arum di Dusun Giriloyo, peran kelompok batik tulis Sekar Arum dalam memberikan kontribusi pada ketahanan ekonomi keluarga di Dusun Giriloyo, Desa Wukirsari, Kecamatan Imogiri, Kabupaten Bantul, Daerah Istimewa Yogyakarta, serta kendala-kendala dan upaya yang ada di lapangan.

Angkatan kerja di D.I Yogyakarta pada Februari 2019 sebanyak 2,201 juta orang. Tingkat Partisipasi Angkatan Kerja (TPAK) juga meningkat 0,95 persen poin dalam waktu setahun terakhir. TPAK Februari 2019 sebesar 73,16 persen. Tingkat Pengangguran Terbuka (TPT) D.I Yogyakarta Februari 2019 sebesar 2,86 persen, mengalami penurunan 0,2 persen poin dibanding TPT Februari 2018 sebesar 3,06 persen. Penduduk yang bekerja di DI. Yogyakarta sebanyak 2,138 juta orang, bertambah 61,57 ribu orang dari Februari 2018. Selama setahun terakhir, lapangan pekerjaan yang mengalami peningkatan persentase penduduk yang bekerja terutama pada Perdagangan (1,56 persen poin), Pertanian (1,39 persen poin), dan Konstruksi (1,17 persen poin). Sementara lapangan pekerjaan yang mengalami penurunan terutama Industri Pengolahan (3,62 persen poin), Jasa Perusahaan (1,14 persen poin), serta Informasi dan Akomodasi (0,58 persen poin). Februari 2019 sebanyak 1,084 juta orang (50,7 persen) bekerja pada kegiatan informal turun 0,9 persen poin dibandingkan Februari 2018 sebesar 51,6 persen. Persentase tertinggi pada Februari 2019 adalah pekerja penuh (jam kerja minimal 35 jam per minggu) sebesar 68,72 persen. Pekerja tidak penuh, yaitu pekerja paruh waktu $(24,9$ persen $)$ dan pekerja setengah penganggur (6,39 persen) (Badan Pusat Statistik-A, 2020).

Permasalahan ketenagakerjaan di DIY tidak hanya untuk menurunkan jumlah penganggur terbuka, tetapi lebih jauh untuk mendorong peningkatan produktivitas Tenaga, karena faktor ini berbanding lurus dengan jumlah kemiskinan yang masih diatas rata-rata nasional (Dinas Nakertrans, 2019).

Analisis Kelayakan Usaha Pembuatan Spare Part kendaran bermotor dan bengkel diteliti Permana Y. (2014) yang dikaji yaitu aspek pasar, teknis, sumber daya manusia, legal dan lingkungan, dan finansial. Berdasarkan hasil analisis finansial diperoleh Payback Period selama 3 tahun 2 bulan, Net Present Value sebesar Rp. 323.268.222, dan Internal Rate of Return sebesar 46,2\%. Dalam meningkatkan penjualan terdapat beberapa cara, namun menurut penelitian yang dilakukan oleh Siregar M.Y. (2017) Untuk meningkatkan penjualan cara yang efektif dengan melakukan promosi. 
Tabel 1. Perkembangan Jumlah kendaraan bermotor Tahun 2012-2018

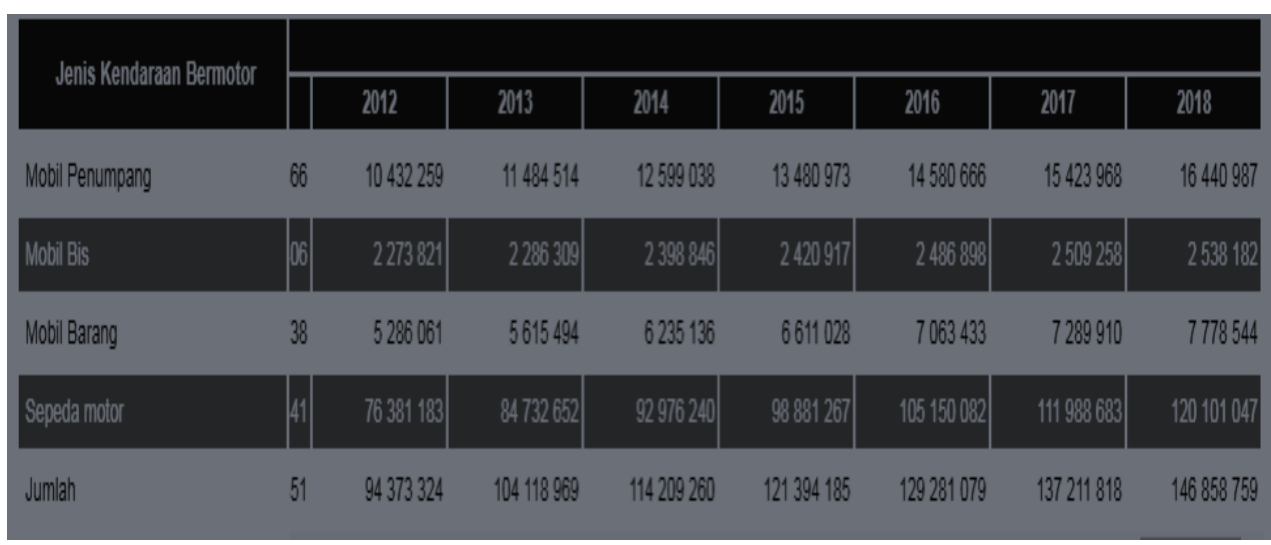

Sumber: Badan Pusat Statistik-B, 2020

Apabila kita melihat data pada tabel 1 maka dapat diambil kesimpulan bahwa jumlah kendaraan bermotor dari tahun 2012 sampai dengan tahun 2018 meningkat. Dengan meningkatnya jumlah kendaraan bermotor maka terbuka peluang usaha di bidang otomotif.

Tujuan kegiatan pengabdian masyarakat ini agar anggota kelompok Pemuda Wonokromo II memiliki wawasan untuk berwirausaha dan dapat meningkatkan ketahanan ekonominya.

\section{METODE}

Kegiatan pengabdian masyarakat kepada mitra dengan cara memberikan ceramah, brosur dan pelatihan sehingga diharapkan dapat meningkatkan pengetahuan, semangat peserta dan rasa percaya diri. Materi pelatihan yang diberikan diantaranya presentasi mengenai ketahanan ekonomi, analisis bisnis part otomotif, contoh-contoh perhitungan produksi pembuatan komponen otomotif lebih banyak lagi beserta analisis harga pasar sehingga dapat lebih membuka wawasan peserta kegiatan yang mencakup harga pokok produksi dan cara menetapkan sasaran bisnis untuk meningkatkan pemahaman mitra mengenai pemanfaatan pengetahuan otomotif secara bijaksana dalam rangka mendukung ketahanan ekonomi keluarga.

Sasaran kegiatan pengabdian masyarakat adalah anggota Kelompok Pemuda Wonokromo II. Anggota kelompok pemuda yang mengikuti kegiatan masih bersekolah di tingkat sekolah menengah atas, lulus sekolah menengah atas dan kuliah. Jumlah peserta kegiatan 25 orang. Kegiatan dilakukan selama dua hari, durasi waktu kegiatan setiap materi disertai dengan tanya jawab adalah selama 1,5 jam. Dengan rincian 30 menit presentasi dan 60 menit sesi tanya jawab. 
Sebagai indikator peserta paham dengan cara diberikan pertanyaan secara lisan kepada peserta pada awal presentasi dan pada akhir presentasi, pertanyaan diberikan kepada semua peserta. Selain itu juga dilihat dari antusiasme peserta kegiatan dalam mengikuti presentasi. Antusiasme peserta dalam mengikuti kegiatan juga dapat dilihat dari jumlah peserta pada saat awal kegiatan sampai akhir kegiatan apakah terdapat pengurangan jumlah peserta atau tidak. Antusiasme peserta juga dapat dilihat dari sikap peserta pada saat mengikuti kegiatan presentasi dan kegiatan tanya jawab secara lisan yang diberikan oleh tim pengabdian.

Tahap kegiatan pengabdian masyarakat melalui tiga tahap, yaitu:

1. Tahap persiapan, pada tahap ini terbagi menjadi tahap perizinan dan persiapan materi kegiatan, seperti leaflet dan materi power poin. Pada tahap ini juga dilaksanakan perencanaan jadwal kegiatan serta perencanaan kegiatan per sesi acara. Pada tahap persiapan kegiatan ini juga ditetapkan sasaran peserta serta dilakukan survei mengenai provile calon peserta kegiatan pengabdian masyarakat.

2. Tahap pelaksanaan kegiatan pengabdian masyarakat

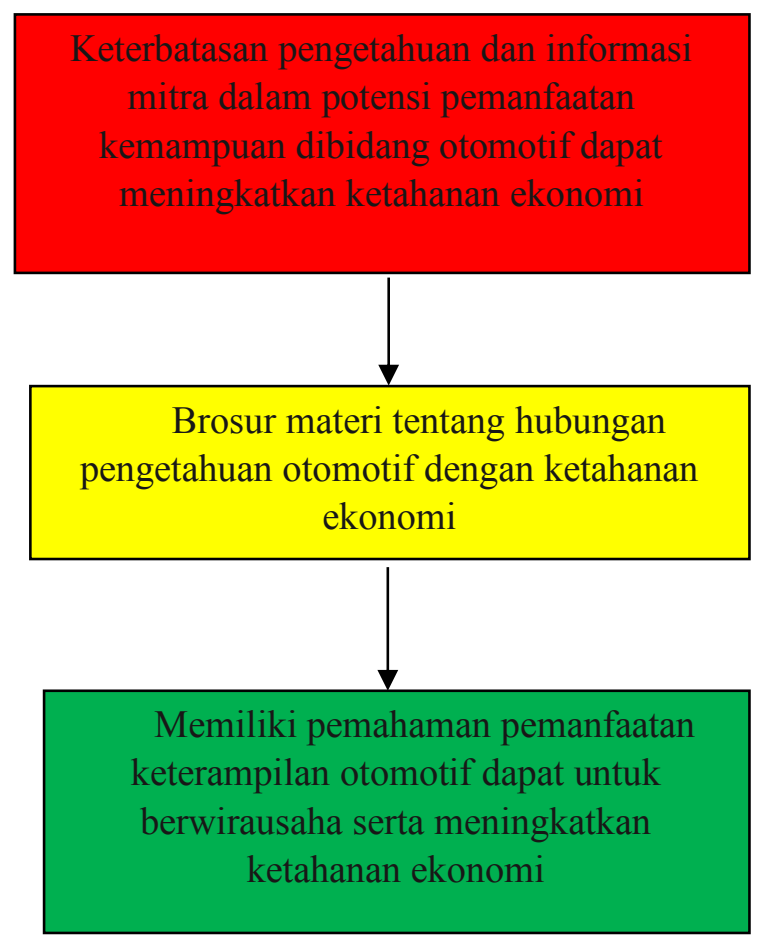

Gambar 1. Gambaran IPTEK yang akan ditransfer 
Kegiatan pengabdian masyarakat dilaksanakan pada hari sabtu dan minggu tanggal 3 hingga 4 Februari 2018, pada pukul 09.00-selesai, kegiatan pengabdian masyarakat dilaksanakan di Sekolah Tinggi Teknologi Adisutjipto, Daerah Istimewa Yogyakarta.

\section{PEMBAHASAN}

Hasil kegiatan pengabdian masyarakat dijelaskan dengan tiga indikator, yaitu:

1. Kehadiran peserta kegiatan

Kegiatan pengabdian masyarakat yang dilakukan oleh tim pengabdian Sekolah Tinggi Teknologi Adisutjipto ini berlangsung dengan lancar. Kegiatan ini terbagi menjadi dua hari, pada hari pertama dilakukan presentasi dan tanya jawab mengenai hubungan ketahanan ekonomi dengan meningkatnya kesejahteraan masyarakat. Pada hari kedua dilakukan presentasi mengenai peluangpeluang usaha yang dapat dilakukan oleh anggota Kelompok Pemuda Wonokromo II beserta hitungan matematis contoh produksi sparepart kendaraan bermotor beserta jenis bahan yang dibutuhkan. Peserta kegiatan pengabdian masyarakat yang hadir sesuai kesepakatan yaitu 25 anggota kelompok pemuda. Pada dua hari kegiatan kehadiran peserta tidak terdapat perubahan jumlah dan personil yang hadir. Peserta yang hadir mengikuti kegiatan pengabdian masyarakat dari awal sampai akhir kegiatan.

2. Antusiasme peserta dalam mengikuti kegiatan

Peserta mengikuti kegiatan pengabdian masyarakat cukup antusias, hal ini ditandai dengan cukup banyak peserta yang menjawab pertanyaan dari presenter serta terdapat beberapa peserta yang bertanya kepada presenter mengenai materi yang disampaikan. Kegiatan presentasi dan tanya jawab dari peserta cukup hidup, tidak hanya diskusi satu arah atau hanya dari presenter saja yang aktif namun peserta kegiatan cukup aktif sehingga melampaui waktu yang telah direncanakan sebelum kegiatan.

Metode yang digunakan adalah metode ceramah yang banyak digunakan disekolah. Metode ceramah adalah cara penyajian pelajaran yang dilakukan guru dengan penuturan atau penjelasan lisan secara langsung terhadap siswa (Fithriyah E. A., 2017).

Metode tanya jawab merupakan suatu cara untuk menyampaikan atau menyajikan bahan pelajaran dalam bentuk pertanyaan dari guru yang harus dijawab oleh siswa atau sebaliknya. Oleh karena itu, dalam penerapannya, guru dan siswa harus terlibat dalam aktifitas bertanya dan memberikan respon atas pertanyaan-pertanyaan yang ada (Basrudin B., dkk, 2013). 
Pada kegiatan pengabdian masyarakat ini terdapat beberapa kendala yang dihadapi oleh tim pengabdi yaitu pada hari kedua kegiatan pengabdian masyarakat diawali mundur 30 menit dari waktu yang direncanakan, hal ini karena keterlambatan peserta kegiatan. Kendala lainnya pada saat presentasi terjadi kematian listrik 30 menit, hal ini dimanfaatkan oleh tim pengabdi untuk sesi tanya jawab.

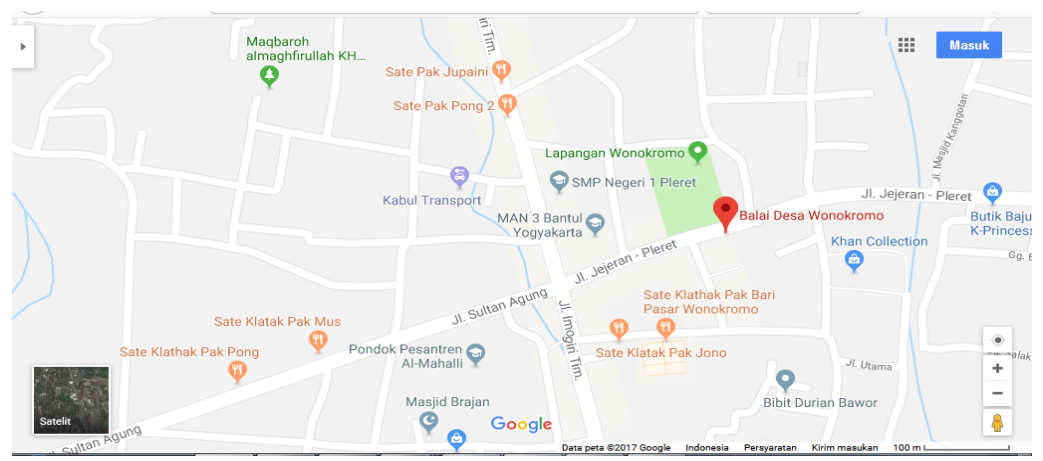

Gambar 2. Balai desa Wonokromo (Balai Desa Wonokromo, 2017)

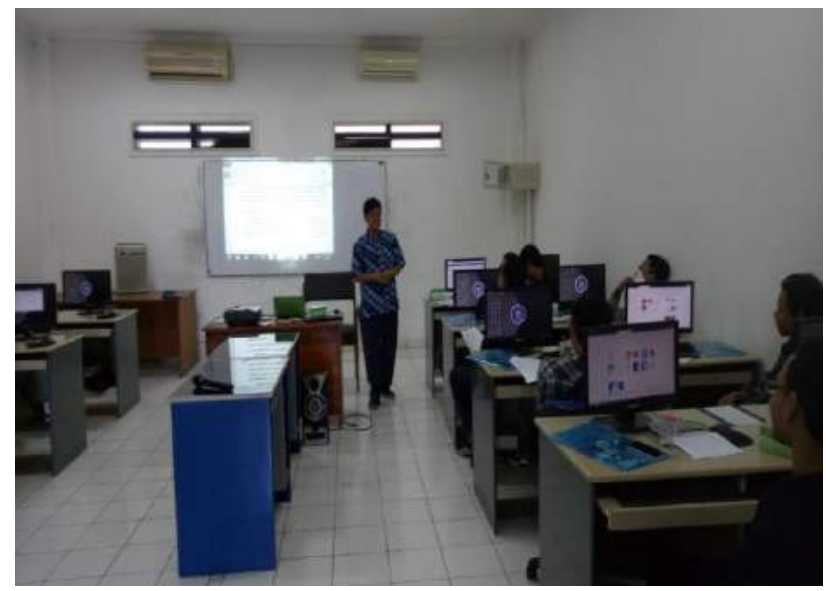

Gambar 2. Pengabdi melakukan presentasi makalah pengabdian masyarakat 


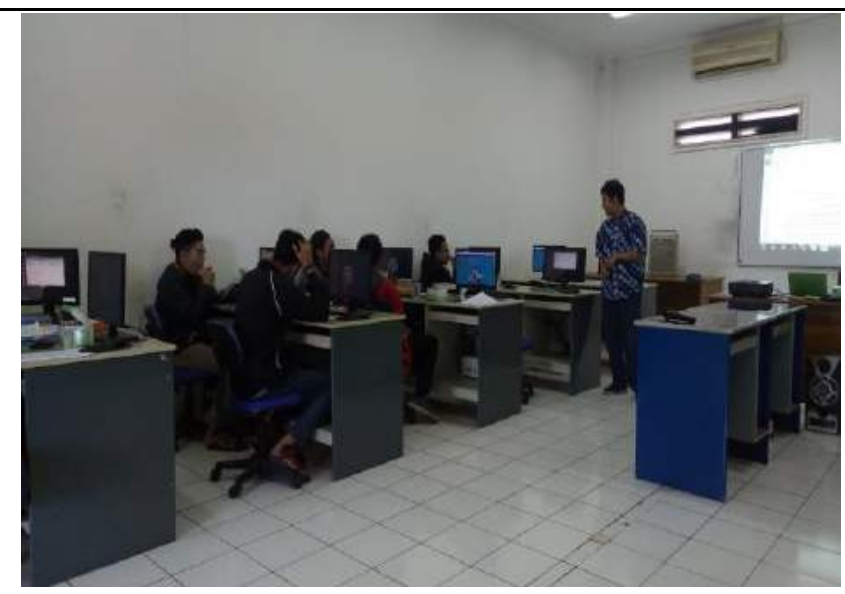

Gambar 3. Pengabdi melakukan kegiatan tanya jawab dengan peserta kegiatan

Dari hasil survei diketahui bahwa latar belakang terbentuknya kelompok pemuda adalah sebagai makhluk sosial, manusia memiliki kecenderungan untuk membentuk suatu kelompok yang memiliki visi dan misi yang sama. Persatuan muda mudi Wonokromo II ini berlokasi di RT 05 Wonokromo II, Pleret, Bantul. Organisasi ini dibentuk oleh pemerintah sejalan dengan kebijakan otonomi daerah. Organisasi kepemudaan ini dibentuk juga berfungsi sebagai media latihan berorganisasi dan media penyaluran minat bakat bagi para pemuda. Fluktuasi keanggotaan dan kegiatan terjadi pada kelompok ini. Secara struktural organisasi ini terdiri dari seorang ketua, dua sekretaris, dua bendahara, dan beberapa seksi salah satunya seksi pengembangan keterampilan sebagai wadah berbagi pengalaman dan keterampilan antar anggota.

Keanggotaan persatuan muda mudi Wonokromo II bervariasi dalam berbagai latar belakang. Warga yang menempuh pendidikan sekolah menengah atas hingga lulus perguruan tinggi secara otomatis akan menjadi anggota. Persatuan muda mudi Wonokromo II juga terdiri dari berbagai usia. Pada tahun 2018 anggota persatuan muda mudi Wonokromo II yang memiliki latar belakang SMU berjumlah 27 orang, yang masih kuliah 13 orang dan lulus SMU namun tidak kuliah terdiri dari 14 orang. Jumlah sebaran anggota tersebut dipandang sangat strategis untuk membekali anggotanya dengan berbagai keterampilan. Mengingat daerah Wonokromo yang berpotensi akan bidang otomotif, pemberian wawasan tentang otomotif diharapkan mampu mendukung perluasan lapangan kerja sehingga baik anggota yang setelah lulus sekolah menengah atas langsung bekerja maupun yang melanjutkan ke perguruan tinggi mampu mengembangkan potensi daerah di bidang otomotif ke pasar lokal. 
Komitmen organisasi untuk meningkatkan kualitas anggota dari tahun ke tahun tidak lepas dari adanya berbagai usaha memberikan program-program pendidikan berbasis otomotif. Sebagai kelompok yang berdiri tahun 2010, wadah ini terus menerus melakukan terobosan untuk meningkatkan kualitas anggotanya. Salah satu faktor usaha tersebut dapat dilakukan dengan memberikan wawasan tentang otomotif, diharapkan dengan terbukanya wawasan para anggota dapat mendukung ketahanan ekonomi keluarga.

Sarana dan prasarana yang dimiliki Persatuan Muda Mudi Wonokromo II saat ini terdiri dari ruang sekretariat berukuran $10 \mathrm{~m}^{2}$ sedangkan yang dibutuhkan berukuran $20 \mathrm{~m}^{2}$, memiliki 2 buah meja padahal yang dibutuhkan 4 meja. Sedangkan Persatuan Muda Mudi Wonokromo II tidak memiliki komputer dan projector, padahal mereka membutuhkan komputer dan projector. Sarana prasarana tersebut dibutuhkan oleh kelompok pemuda untuk menjalankan kegiatan organisasinya. Selain keterbatasan dalam hal sarana dan prasarana anggota kelompok pemuda juga memiliki kendala dalam menambah pengetahuan dan wawasan terutama wawasan dalam berwirausaha. Padahal apabila kita melihat situasi di sekitar lokasi banyak terdapat pedagang onderdil sepeda motor dan disekitar lokasi sudah dikenal oleh masyarakat Yogyakarta pada khususnya sebagai pasar onderdil kendaraan bermotor mobil, sepeda motor bahkan sepeda dengan harga yang relatif terjangkau untuk semua kalangan masyarakat.

Selain itu persoalan yang dihadapi kelompok pemuda Wonokromo II adalah kurangnya akses informasi bahwa dengan keterampilan di bidang otomotif dapat meningkatkan Ketahanan Ekonomi Keluarganya, keterbatasan pengetahuan dan keterampilan anggota kelompok dalam bidang otomotif sehingga dapat berpengaruh terhadap kemampuan berinisiatif dan kejelian untuk berwirausaha serta melihat peluang usaha yang bisa dilakukan, keterbatasan sarana dan prasarana sehingga dapat menyebabkan anggota kelompok pemuda kurang percaya diri.

Pada kegiatan masyarakat ini antusiasme peserta cukup bagus, hal ini ditandai dengan kehadiran 100\% pada dua hari kegiatan. Selain dari kehadiran juga terlihat dari antusiasme dalam menjawab dan bertanya dari peserta kepada presenter. Pada awal kegiatan pengabdian masyarakat hanya terdapat $40 \%$ peserta yang bisa menjawab pertanyaan, namun pada akhir kegiatan pengabdian masyarakat $100 \%$ peserta bisa menjawab pertanyaan dari presenter. 


\section{SIMPULAN}

Kegiatan pengadian masyarakat kepada Kelompok Pemuda Wonokromo II pada tanggal 3 sampai 4 Februari 2018, pada pukul yang dimulai pada jam 09.00 WIB di Sekolah Tinggi Teknologi Adisutjipto, Daerah Istimewa Yogyakarta berjalan dengan lancar dan sesuai dengan rencana, antusiasme peserta cukup bagus ditandai dengan kegiatan tanya jawab. Peserta mengikuti kegiatan pengabdian masyarakat dari awal sampai akhir kegiatan. Peserta menyarankan mengenai materi strategi pemasaran produk yang mereka hasilkan.

\section{DAFTAR PUSTAKA}

Basrudin, B., Ratman, R., Gagaramusu, Y. 2013. Penerapan Metode Tanya Jawab untuk Meningkatkan Hasil Belajar Siswa Pada Pokok Bahasan Sumber Daya Alam di Kelas IV SDN Fatufia Kecamatan Bahodopi. Jurnal Kreatif Online, Vol 1(1), hal. 214-227

Fithriyah, E. A., Mutaminah, M. 2017. Pengaruh Metode Ceramah Dan Tanya Jawab Terhadap Prestasi Hasil Belajar Siswa Kelas 5 SDN Paromahan Kecamatan Tambak Kabupaten Gresik. Jendela Pendidikan: Jurnal Ilmiah Keguruan dan Ilmu Pendidikan, Vol 6(2), hal.167-180.

Marlinah, L. 2017. Meningkatkan Ketahanan Ekonomi Nasional Melalui Pengembangan Ekonomi Kreatif. Cakrawala-Jurnal Humaniora, Vol 17(2), hal.258-265.

Nasution, A. P., Pristiyono, P. 2019. Antisipasi Ketahanan Ekonomi Keluarga Di Kabupaten Labuhanbatu Selatan. ECOBISMA (Jurnal Ekonomi, Bisnis dan Manajemen), Vol 6(1), hal.9097.

Nursaid, A., Armawi, A. 2016. Peran Kelompok Batik Tulis Giriloyo Dalam Mendukung Ketahanan Ekonomi Keluarga (Studi Di Dusun Giriloyo, Desa Wukirsari, Kecamatan Imogiri, Kabupaten Bantul, Daerah Istimewa Yogyakarta). Jurnal Ketahanan Nasional, Vol 22(2), hal.217-236.

Permana Y., Saleh A., Bakar A. 2014. Analisis Kelayakan Usaha Pembuatan Spare Part Dudukan Mesin dan Transmisi Mobil Di Bekasi, Reka Integra ISSN: 2338 -5081 Jurusan Teknik Industri Itenas No.02 Vol.02 Jurnal Online Institut Teknologi Nasional April 2014, hal.376-387 
Siregar, M. Y., Winita, W. 2017. Faktor-Faktor Yang Mempengaruhi Volume Penjualan Sparepart Pada PT. Calispo Multi Utama Medan. Jurnal Akuntansi Dan Bisnis: Jurnal Program Studi Akuntansi, Vol 3(1), hal.105-120

Subarjo, A. H., Mardwianta, B., Ahmadi, N. 2019. Peningkatan Pengetahuan Ketahanan Ekonomi Melalui Keterampilan Otomotif Pada Siswa Ibnu Sina. KACANEGARA Jurnal Pengabdian pada Masyarakat, Vol 2(1), hal.49-54.

Sumber internet:

Badan Pusat Statistik-A. 2020. Keadaan Ketenagakerjaan Yogyakarta Februari 2019, [internet] diakses dari: https://yogyakarta.bps.go.id/pressrelease/2019/05/06/953/keadaan-ketenagakerjaan Yogyakarta-februari-2019.html, pada tanggal 4 April 2020, jam 19.30 WIB.

Badan Pusat Statistik-B. 2020. Perkembangan Jumlah Kendaraan Bermotor Menurut Jenis, 19492018, [internet] diakses dari: https://www.bps.go.id/linkTableDinamis/view/id/1133, pada tanggal 3 April 2020, jam 20.32 WIB.

Balai Desa Wonokromo. 2017. Peta Balai Desa Wonokromo. [internet] Diakses dari http://googlemap/ peta-balai desa wonokromo pada hari rabu 20 Desember 2017 jam 01:23 WIB.

Dinas Nakertrans. 2019. Tingkat Penganggur Terbuka DIY Februari 2019 Turun menjadi 2,86\%, [internet] diakses dari: https://jogjaprov.go.id/berita/detail/7726-tingkat-penganggur-terbukadiy-februari-2019-turun-menjadi-2-86, pada tanggal 4 April 2020 jam 19:40 WIB. 